\title{
PENGGUNAAN METODE PEMBELAJARAN MULTIMEDIA BERBASIS OBJECT-ORIENTED PROGRAMMING (ADOBE-FLASH) PADA MATA PELAJARAN BAHASA INGGRIS
}

\author{
Resty Wahyuni \\ Surel : restywahyuni@umsu.ac.id
}

\begin{abstract}
The aim of the research are (1) to know an influence on the development of Adobe-Flash multimedia programs on the ability of students to improve vocabulary skills in English. (2) to find the percentage of the influence of the development of multimedia programs on the ability of students to improve vocabulary skills in English. This research is an experimental research. The program implementation technique for this research is a preliminary test used to measure students' vocabulary abilities of the material being taught while the final test is carried out to determine student learning outcomes after being treated using Multimedia-based ObjectOriented Programming (AdobeFlash) learning methods in English.
\end{abstract}

Keywords: Multimedia-Based Learning Method, Vocabulary Skills, English.

\begin{abstract}
ABSTRAK
Tujuan dalam penelitian ini yaitu (1) untuk mengetahui bagaimana pengaruh pengembangan program multimedia Adobe-Flash terhadap kemampuan mahasiswa dalam meningkatkan keterampilan kosakata pada mata pelajaran bahasa Inggris; (2) untuk mengetahui persantase pengaruh pengembangan program multimedia terhadap kemampuan mahasiswa dalam meningkatkan keterampilan kosakata pada mata pelajaran bahasa Inggris. Penelitian ini adalah penelitian eksperimental. Dimana Teknik dalam pelaksanaan untuk program dalam penelitian ini yaitu dengan pemberian tes awal digunakan untuk mengukur kemampuan kosakata mahasiswa terhadap materi yang diajarkan, sedangkan tes akhir dilakukan untuk mengetahui hasil kosakata belajar mahasiswa setelah diberikan perlakuan dengan menggunakan metode pembelajaran multimedia berbasis Object-Oriented Programming (AdobeFlash) pada mata pelajaran bahasa Inggris.
\end{abstract}

Kata Kunci: Metode Pembelajaran Multimedia Keterampilan Kosakata, Pelajaran Bahasa Inggris.

\section{PENDAHULUAN}

Kosakata merupakan bagian utama dalam pembelajaran Bahasa Inggris. Dalam menguasai kosakata yang sifatnya esensial dalam beberapa keterampilan seperti keterampilan berbahasa, baik keterampilan reseptif (listening dan reading) maupun keterampilan produktif (speaking and writing). Belakangan ini semakin banyak sekali mendapat berbagai perhatian yang serius dari beberapa orang. Contohnya seperti yang dirilis oleh The US National Reading Panel pada ikhtisarnya yang mencantumkan secara jelas bagaimana pentingnya setiap kosakata yang diajarkan baik dengan secara langsung dalam sebuah 


\section{SCHOOL EDUCATION JOURNAL VOLUME 11 NO. 2 JUNI 2021}

pengajaran reading (Hiebert \& Kamil,2005:.7). Pentingnya kosakata dalam pembelajaran bahasa juga diilustrasikan oleh Wilkins (Thornbury, 2002:13), yang menyatakan bahwa "without grammar, little can be conveyed; without vocabulary, nothing can be conveyed". Lebih lanjut dia mengemukakan bahwa dengan mempelajari kosakata seseorang akan dapat meningkatkan kemampuan berbahasa dengan cepat. Dari pernyataan tersebut dapat disimpulkan bahwa untuk kepentingan komunikasi kosakata lebih penting daripada tata bahasa. Masalahnya di negara Indonesia, pembelajaran bahasa Inggris telah diajarkan sebagai sesuatu Bahasa yang asing, sehingga dalam penggunaannya pada saat berkomunikasi dengan masyarakat yang sangat terbatas (Sadtono, 2007:205). Sebagai akibatnya, banyak mahasiswa, terutama mahasiswa yang berada pada jurusan bahasa Inggris hanya mampu mendapat beberapa masukan berupa leksikon dalam bahasa Inggris yang jumlahnya sangat relatif sedikit. Sehingga terlihat tidak mengherankan apabila ada mahasiswa yang kerap telah mengalami beberapa kesulitan dalam memahami beberapa makna, yang ditinjau dari segi tekstual maupun dari segi kontekstual berdasarkan kata-kata yang diperoleh dari dalam suatu teks. Kesulitan yang diperoleh ini dapat menjadi sebuah masalah yang sangat serius, sebab yang menjadi fokus utama setelah kita berhasil lulus dari program studi
Bahasa Inggris yaitu dengan mahasiswa mampu berbahasa Inggris dengan baik.

Harrison (2008:88) dalam penelitiannya telah menyatakan bahwa dukungan dari sebuah komputer sangat memiliki manfaat sebagai bentuk dalam pengembangan beberapa penguasaan dalam kosakata. Harrison telah mencontohkan ada beberapa sebagai temuan, antara lain yang dinyatakan oleh Reinking \& Rickman (1990:98) dan Davidson, Elcock \& Noyes (1996). Harrison yang juga memebrikan sebuah kesimpulan dari Ruddell (1994:97) yang sangat sangat berguna dalam membimbing dan memandu dalam pengajaran beberapa kosakata, dimana beberapa antara lain menyatakan: (1) Kosakata yang akan dipahami akan dilakukan secara bertahap, tidak mampu diserap sekaligus secara langsung maupun ditolak dalam waktu sekaligus, (2) Mahaiswa yang mampu belajar dengan beberapa kosakata dengan lebih sangat efektif jika pembelajarannya dilakukan dengan cara aktif dan sosial, (3) Mahasiswa mampu dan dapat belajar beberapa kosakata berdasarkan dari beberapa konteks. Seperti dalam kutipan National Reading Panel (2000:44) yang berjudul "Specific Conclusions about Vocabulary Instruction"e menyatakan bahwa pada salah satu dari kesimpulannya yaitu bahwa pernyataan "teknologi komputer yang bisa digunakan dengan secara lebih efektif untuk mampu membantu 
Resty wahyuni : Penggunaan Metode Pembelajaran ...

dalam mengajarkan beberapa kosakata".

Terdapat contoh berupa authoring tool dalam sebuah pemprograman yang berbasis pada sebuah objek (Objectoriented Programming) sebagai contoh seperti aplikasi yang sering didengar yaitu Adobe Flash. Adobe Flash, adalah sebuah program berupa authoring tool dimana sangat banyak telah digunakan dalam menghasilkan beberapa konten berupa komten multimedia dan konten animasi.

Adobe Flash yang dapat kita gunakan dalam berbagai jenis keperluan, contohya seperti untuk desain web, kemudian digunakan sebagai galeri foto, dalam presentasi interaktif, dan lain sebagainya. Adobe Flash yang menggunakan sebuah system yang pemprogramannya itu berorientasi pada objek (OOP), dimana sangat memudahkan bagi perancang untuk multimedia dalam mengorganisir beberapa objek-objek yang jumlahnya sangat beragam (misalnya seperti beberapa kumpulan gambar dan beebrapa jenis video/animasi), karena beberapa cara kerjanya hampir mirip dengan cara kerja bagaimana seorang manusia mampu untuk mengelola benda-benda yang ada dalam lingkungan sekitarnya (Dean \& Dean, 2008:197198).

Selain daripada itu, ada beberapa pula dari komponen yang akan sudah mampu tersedia dengan secara default, seperti contohnya pada checkbox, lalu radio button, selanjutnya pada slider, dan juga dapat ditemukan pada pemutar video. Semua dari komponen-komponen ini akan dapat secara dengan mudah akan dipanggil dan akan dimodifikasi dengan cara yang sesuai keperluan.

Berdasarkan dari hasil yang diperoleh pada pra-survei ini terungkap beberapa hal yang menyatakan bahwa sebagian besar dari dosen tersebut belum pernah untuk memeproleh atau mendapat pelatihan berupa bimbingan dalam hal menggunakan beberapa perangkat sebagai multimedia. Pernyataan tersebut sangat mengecewakan, sebab beberapa responden dengan optimis menyatakan sebuah pendapat bahwa Ketika berada di sekolahnya mampu menyediakan, terdapat fasilitas yang sangat memadai yang mampu digunakan untuk menjalankan perangkat sebuah multimedia. Berdasarkan latar belakang yang dikemukakan diatas dan dari masalah yang dipaparkan di atas, penelitian yang dilakukan ini berfokus pada sebuah proses pengembangan sebuah program multimedia dimana nantinya yang mampu layak untuk ditinjau dari beberapa aspek seperti asepek materi, aspek media dan aspek penggunaan, sehingga mampu meningkatkan beberapa penguasaan dari kosakata dalam Bahasa Inggris pada mahasiswa semester II. Adapun tujuan dari penelitian tersebut adalah untuk menghasilkan sebuah program multimedia yang cukup layak pakai jika ditinjau dari aspek materi dan aspek media, dan dapat digunakan dalam pengajaran Bahasa Inggris, khususnya untuk meningkatkan 
penguasaan kosakata mahasiswa semester II UMSU.

Program ini akan dikembangkan dengan langkahlangkah seeprti (1) memberikan menu utama dimana berisi pendahuluan (Standar Kompetensi, Kompetensi Dasar, Indikator, dan juga berupa ringkasan materi), (2) memberikan berupa materi pembelajaran dan (3) memberikan soal berupa latihan.

Tujuan penelitian ini adalah: Untuk mengetahui bagaimana pengaruh pengembangan program multimedia terhadap kemampuan mahasiswa dalam meningkatkan keterampilan kosakata pada mata pelajaran bahasa Inggris. Untuk mengetahui seberapa besar pengaruh pengembangan program multimedia terhadap kemampuan mahasiswa dalam meningkatkan keterampilan kosakata pada mata pelajaran bahasa Inggris.

\section{METODE PENELITIAN}

Penelitian yang dilakukan ini merupakan Penelitian Eksperimental. Penelitian ini dilakukan di FKIP UMSU. Waktu penelitian dilaksanakan pada semester genap tahun pelajaran 2019/2020. Populasi penelitian ini adalah seluruh mahasiswa semester II pendidikan Bahasa Inggris. Random sampling dijadikan sebagai sampel penelitian yang mana satu kelas sebagai kelas eksperimen yang diajarkan dengan pengembangan program pembelajaran multimedia dan satu kelas lagi sebagai kelas kontrol yang diajarkan dengan model pembelajaran group investigation yaitu kelas II A Pagi dan kelas II C Pagi Prodi Bahasa Inggris FKIP UMSU. Instrumen yang digunakan dalam penelitian adalah tes.

Dalam penelitian ini tes yang diberikan pada siswa bertujuan untuk mengetahui kemampuan keterampilan menulis mahasiswa. Tes yang diberikan berbentuk tes uraian. Adapun tes terdiri dari :

- Tes Awal (pre-test)

Tes ini digunakan untuk mengukur kemampuan awal siswa terhadap kosa kata mahasiswa.

- Tes Akhir (post-test)

Tes akhir (post-test) merupakan tes yang diberikan kepada mahasiswa setelah dilakukan pembelajaran pada kedua kelas, dimana kelas control dosen masih menggunakan metode ceramah, sedangkan pada kelas eksperimen dosen sudah menggunakan pengembangan program multimedia Adobe Flash. Tes akhir bertujuan untuk melihat hasil kosa kata mahasiswa dengan atau tanpa pengembangan program multimedia Adobe Flash.

\section{HASIL PENELITIAN DAN PEMBAHASAN}

Sebagai gambaran secara umum, mengenai distribusi data penelitian yang diperoleh di lapangan, maka data yang ada dideskripsikan berupa data yang telah diolah dari data mentah yang telah diperoleh dengan menggunakan bentuk analisa sebagai berikut: 
Resty wahyuni : Penggunaan Metode Pembelajaran ...

- Pre-test

Adapun hasil pre-test dalam penelitian ini dapat dilihat pada tabel di bawah ini:

Table 1. Data Nilai Ketuntasan Mahasiswa Pre-Test

\begin{tabular}{c|c|c|c}
\hline Nilai & $\begin{array}{c}\text { Jumlah } \\
\text { Mahasiswa }\end{array}$ & Presentase & Ket \\
\hline$\geq 75$ & 21 & $56,7 \%$ & $\begin{array}{c}\text { Tidak } \\
\text { Lulus }\end{array}$ \\
\hline$<75$ & 16 & $43,24 \%$ & Lulus \\
\hline
\end{tabular}

Pada perhitungan hasil pre-test di atas, diperoleh hasil dari kemampuan menulis mahasiswa diklasifikasikan kedalam dua kategori, yaitu lulus dan tidak lulus. Adapun yang dikategorikan tidak lulus berjumlah 21 mahasiswa dengan persentase $56,76 \%$, dan yang dikategorikan lulus berjumlah 16 orang mahasiswa dengan persentase $43,24 \%$.

- Post-test

Adapun hasil post-test dalam penelitian ini dapat dilihat pada table di bawah ini:

Tabel 2. Data Nilai Ketuntasan Siswa Post-Test

\begin{tabular}{c|c|c|c}
\hline Nilai & $\begin{array}{c}\text { Jumlah } \\
\text { Siswa }\end{array}$ & Presentase & Ket \\
\hline$\geq 75$ & 5 & $13,51 \%$ & $\begin{array}{c}\text { Tidak } \\
\text { Lulus }\end{array}$ \\
\hline$<75$ & 32 & $86,49 \%$ & Lulus \\
\hline
\end{tabular}

Pada perhitungan hasil posttest diatas, diperoleh hasil dari kemampuan menulis mahasiswa diklasifikasikan kedalam dua kategori, yaitu lulus dan tidak lulus. Adapun yang dikategorikan tidak lulus sebanyak 5 orang mahasiswa dengan persentase $13,51 \%$ dan yang dikategorikan lulus sebanyak 12 orang siswa dengan persentase $86,4 \%$.

\section{Uji Normalitas Data}

Uji normalitas digunakan untuk melihat apakah data yang diperoleh berdistribusi normal atau tidak. Hasil perhitungan uji normalitas dengan menggunakan rumus Liliefors (L).

- Pre-test

Berdasarkan pengujian uji normalitas pada saat pre-test diperoleh Lhitung $=-0,901$ sedangkan Ltabel pada taraf nyata $a=0,05$ dan $\mathrm{n}=37$ diperoleh Ltabel $=0,146$. Karena Lhitung < Ltabel $(-0,901<$ 0,146) maka dapat disimpulkan bahwa data berdistribusi normal.

- Post-test

Hasil Pengujian Uji

Normalitas pada post-test diperoleh Lhitung $=-0,855$ sedangkan Ltabel pada taraf nyata $\mathrm{a}=0,05$ dan $\mathrm{n}=37$ diperoleh Ltabel $=0,146$. Karena, Lhitung < Ltabel $(-0,855<0,146)$ sehingga dapat dikatakan bahwa data distribusi normal. 


\section{Uji Homogenitas}

Uji homogenitas untuk mengetahui apakah data memiliki sampel yang homogen atau tidak. Varians Pre-test $=209,38$ Varians Post-test $=142,32 \mathrm{a}=37 \mathrm{~F}=$ Varian Terbesar $=209,38=1,471$ Varian Terkecil $=142,32$ Berdasarkan hasil perhitungan diatas, diperoleh Fhitung sebesar 1,471. Sedangkan Ftabel pada taraf nyata $\mathrm{a}=0,05$ dan $\mathrm{dk}=\mathrm{n}-2$ maka $37-2=35$ diperoleh Ftabel $=2,49$.

Jika harga Fhitung dibandingkan dengan Ftabel diperoleh Fhitung < Ftabel $(1,471<2,49)$ maka dapat disimpulkan bahwa pre-test dan post-test yang diujikan 68 untuk mahasiswa FKIP UMSU Tahun Akademik 2019/2020 adalah homogen.

\section{Uji Hipotesis Data}

Uji hipotesis dimaksudkan untuk mengetahui apakah ada pengaruh pembelajaran metode Multimedia berbasis object-oriented programming (AdobeFlash) pada mata pelajaran bahasa Inggris untuk mahasiswa Program Studi Bahasa Inggris FKIP UMSU. Dalam hal ini uji-t dapat diterima jika thitung < ttabel maka perlakuan (treatment) yang diberikan tidak memiliki pengaruh.

Dalam penelitian ini, diketahui nilai thitung sebesar 5,2757 sedangkan ttabel dengan derajat kebebasan $\mathrm{dk}=\mathrm{n} 1=37-1=36$ pada taraf nyata $\mathrm{a}=0,05$ diperoleh ttabel $=$ 1,68830 . Karena thitung $>$ ttabel yaitu $(5,2757>1,68830)$. Maka dapat disimpulkan bahwa hipotesi yang diterima adalah Ha yang artinya ada pengembangan metode pembelajaran MultiMedia berbasis Object-Oriented Programming (Adobe-Flash) pada mata pelajaran bahasa Inggris.

\section{Pembahasan}

Dari hasil tes awal (pre-test) diperoleh nilai rata-rata 69,21 dengan nilai tertinggi 92 dan nilai terendah 39 serta standar deviasinya sebesar 14,47. Berdasarkan hasil tersebut, mahasiswa yang telah mencapai nilai berdasarkan Kriteria Ketuntasan Minimum (KKM) hanya sebanyak 16 orang mahasiswa dengan presentasi $43,24 \%$, sedangkan yang belum mencapai Kriteria Ketuntasan Minimum (KKM) sebanyak 21 orang mahasiswa dengan presentasi 56,76\%. Pada hasil post-test, diperoleh nilai rata-rata 85,30 dengan nilai tertinggi 100 dan nilai terendah 55 serta standart deviasinya 11,93. Berdasarkan hal tersebut siswa yang telah mencapai nilai Kriteria Ketuntasan Minimum (KKM) sebanyak 32 orang siswa dengan presentasi $86,49 \%$, dan yang belum mencapai Kriteria Ketuntasan Minimum (KKM) sebanyak 5 orang siswa dengan presentasi $13,51 \%$.

Pada pengujian normalitas diketahui data berdistribusi normal Lhitung < Ltabel. Berdasarkan hasil pre-test siswa diperoleh nilai Lhitung $=-0,901$ sedangkan Ltabel $=0,146$. Karena Lhitung < Ltabel $(-0,901<$ 0,146 ) maka dapat dikatakan bahwa data pre-test berdistribusi normal. Dan pada post-test diperoleh nilai Lhitung $=0,855$ sedangkan Ltabel $=$ 
Resty wahyuni : Penggunaan Metode Pembelajaran ...

0,146. Karena Lhitung < Ltabel ($0,855<$ Ftabel $(1,471<2,49)$ dan dapat disimpulkan bahwa data memiliki sampel yang homogen. Setelah dianalisis dengan menggunakan uji-T, diperoleh nilai thitung $=5,2757$ sedangkan ttabel $=$ 1,68830. Berdasarkan angka tersebut diperoleh kesimpulan bahwa thitung $>$ ttabel $(5,2757>1,68830)$, maka Ha diterima dan $\mathrm{H} 0$ ditolak, artinya ada pengembangan pembelajaran Multimedia berbasis Object-Oriented Programming (Adobe-Flash) pada mata pelajaran bahasa Inggris.

\section{SIMPULAN}

Setelah melalui proses penelitian dan berdasarkan analisis terhadap data-data yang ada, maka dapat disimpilkan beberapa hal yang merupakan inti dari hasil penelitian ini, sebagai berikut:

Dari hasil penelitian sebelum menggunakan metode pembelajaran multimedia berbasis object-oriented programming (Adobe-Flash) diperoleh nilai rata-rata sebesar 69,21 dengan nilai tertinggi 92 dan nilai terendah 39 serta standart deviasi sebesar 14,47. Berdasarkan hal tersebut mahasiswa yang mencapai (KKM) berjumlah 21 orang mahasiswa dan yang belum mencapai KKM berjumlah 12 Orang mahasiswa.

Dari hasil penelitian sebelum menggunakan metode pembelajaran multimedia berbasis object-oriented programming (Adobe-Flash) diperoleh nilai rata-rata sebesar 85,30 dengan standard deviasi sebesar
11,93. Berdasarkan hal tersebut siswa yang mencapai nilai Kriteria Ketentuan Minimum (KKM) berjumlah 32 Orang dan yang belum mencapai nilai KKM berjumlah 5 orang mahasiswa.

Berdasarkan uji hipotesis diperoleh sebesar 5,2757 pada taraf signifikan $\alpha=0,05$ dan $\mathrm{dk}=\mathrm{n}-1=37$ $2=35$ dari daftar tabel distribusi = 1,68957 hipotesis yang diterima yang dinyatakan adanya metode pembelajaran Multimedia berbasis Object-Oriented (Adobe-Flash) terhadap kosakata pada mata pelajaran bahasa Inggris.

\section{DAFTAR RUJUKAN}

Al-saadi, N. 2015. Importance of English Language in the Development of Tourism. Academic Journal of Accounting and Economics Researches, 4(1), 33-45. Retrieved from www.worldfresearches.com

Dagdilelis, V. 2005. Principles ofeducational software design. Dalam S. Mishra \& R.C. Sharma, Interactive multimedia in education and training (Eds.) (pp.1-24). Hershey: Idea Group Publishing.

Dean, J., \& Dean, R.H. 2008. Introduction to programming with Java: a problem solving approach. New York: McGrawHill.

De Carrico, J. S. 2001. Vocabulary Learning and Teaching. Dalam M. Celce Murcia (Ed.), Teaching English as a Second 
or Foreign Language (3rd ed.) (pp.285-299). Boston: Heinle \& Heinle. Erlbaum Associates, Inc.Kerr, C. \& Keats,

J. 2009. The essential guide to Flash CS4. New York: Friends of Apress.

Gay, L.R. 1987. Educational research: competencies for analysis and application (3rd ed.). Columbus: Merrill Publishing Company.

Nagy, W. 2005. Why vocabulary instruction needs to be longterm and comprehensive. Dalam E.H. Hiebert, \& M. Kamil, Teaching and learning vocabulary; bringing research to practice (Eds) (pp.27-44). London: Lawrence Erlbaum Associates, Inc.Nation, I. S. P. (2001). Learning vocabulary in another

Sato, T., \& Suzuki, A. 2010. Do multimediaoriented visual glosses really facilitate EFL vocabulary learning?: A comparison of planar images with threedimensional images. The Asian EFL

Sugiyono. 2010. Metode penelitian pendidikan: pendekatan kuantitatif, kualitatif, dan $R \& D$. Bandung: Penerbit Alfabeta.

Thornbury, S. 2002. How to teach vocabulary. Edinburgh: Pearson 